\title{
DIAMMONIUM HYDROGEN PHOSPHATE (DAP) AS A CONSOLIDANT IN CARBONATE STONES: IMPACT OF APPLICATION METHODS ON EFFECTIVENESS
}

\author{
A.Murru $^{a, *}$, R. Fort ${ }^{b}$ \\ ${ }^{a}$ Dipartimento di Ingegneria Civile, Ambientale e Architettura, Università di Cagliari, Italy. \\ ${ }^{b}$ Instituto de Geociencias IGEO (CSIC, UCM), Spanish Research Council CSIC - Complutense University of Madrid UCM, Madrid, \\ Spain. \\ * Corresponding author \\ E-mail address: ariannamur@gmail.com (A. Murru)
}

\section{Highlights}

- Consolidation treatment for thermally damaged carbonate rocks.

- Penetration depth capacity of inorganic consolidants (DAP).

- Role of techniques applicative on the consolidation effectiveness results.

- Surface properties modification of carbonatic stones (roughness and colour).

\begin{abstract}
New products such as diammonium hydrogen phosphate (DAP) have yielded good results as consolidants in construction stone used in the architectural heritage. Their effectiveness, which depends on the characteristics of the stone substrate and product concentration, is likewise impacted by the application technique used, which may or may not favour penetration into the stone. This study explored the effectiveness of brush, immersion and poultice application of a $3 \mathrm{M}$ concentration of DAP on limestone and marble. Ultrasonic pulse velocity, colour change, porosity and pore size distribution as well as the variations in anisotropy, roughness and the alteration index were analysed to establish the efficacy of carbonate stone consolidants.

Both stones were penetrated most deeply when the consolidant was applied with a poultice, while the pore structure of limestone favoured more intense penetration.

Applying a poultice yielded good results in marble, improving its mechanical properties without inducing variations in colour or surface roughness. In limestone in turn, immersion delivered the best results, leaving colour unchanged while raising mechanical performance to levels similar to those for the unaltered stone.
\end{abstract}

\section{Keywords}

heritage conservation, consolidation, hydroxyapatite, marble, limestone, application methods, penetration depth.

\section{Declarations of interest: none}




\section{INTRODUCTION}

Diammonium hydrogen phosphate (DAP) is an inorganic consolidant that favours calcium phosphate, primarily hydroxyapatite (HAP), formation. The study of hydroxyapatite precipitation, nucleation and growth [1] is of great interest in biomedical engineering, in particular in connection with the regeneration of bone tissue [2-4]. The product has also been used in studies to consolidate carbonate stone in elements forming part of the historic- architectural heritage [5-10].

To enhance their properties, these treatments are mixed with additives such as $\mathrm{ClCa}_{2}$ or polymers or nanoparticles to favour calcium phosphate phase or other compound formation [11- 17]. Studies are underway on the use of DAP as an HAP precursor to heighten stone resistance to decay in aggressive environments [18-20].

Although the use of phosphates to conserve the cultural heritage is in an experimental stage, the findings show that fostering calcium phosphate (primarily hydroxyapatite) formation in decayed carbonate matrices may be a promising procedure for repairing altered stone. Construction stone cohesion may be affected by cracking or mineral component disintegration induced by agents of decay such as frost, salt crystallisation or thermal shock. A number of authors have used thermal shock, a rapid procedure that generates no byproducts, to accelerate stone ageing [24, 25].

Recent studies have shown that diammonium hydrogen phosphate induces consolidation in decayed carbonate stone by furthering hydroxyapatite (a calcium phosphate) mineralisation in the pore network of the damaged stone [5-8, 29-35]. Chemical and mineralogical compatibility between hydroxyapatite and calcite substrates is attributable to the good match between their lattice parameters [16] and to HAP's higher resistance than calcium carbonate to solubilisation

[7] and hence to decay in acidic environments [34]. A further advantage is the non-toxicity of the solution, both for users and for the environment [32].

One of the key parameters for assessing the effectiveness of diammonium hydrogen phosphate treatment is the penetration depth attained with these new mineral phases $[5,14,36]$.

Successful stone conservation is associated with stone porosity and the techniques used to apply the consolidant [13]. The impact of a number of techniques for applying DAP to the same carbonate stone has been assessed.

\section{RESEARCH AIMS}

This study assessed the penetration depth attained when applying diammonium hydrogen phosphate (DAP) by brushing, immersion or poultice packing to consolidate two types of carbonate stones used in the built heritage, establishing application time on the grounds of capillary absorption. Analytical methods were deployed to determine how effectively the formation of new phosphate mineralogical phases restored cohesion in the decayed stone and ascertain the impact of penetration patterns on that process.

\section{MATERIALS AND METHODS}

\subsection{Stone materials}

Two calcium carbonate lithofacies in the form of calcite, namely marble and limestone, were analysed in this study. Although traditionally used as cladding and in decorative elements in cultural heritage buildings, they are particularly vulnerable to weathering and concomitant decay. 
Carrara marble (Marmo Statuario Michelangelo) is found in the Apuan Alps [37] and quarried in areas of the Carrara basins (Toscana, Italy) [38]. Characterised by a uniform colour with an occasional greyish vein [39,40], it has a crystal size of $150 \mu \mathrm{m}$ to $200 \mu \mathrm{m}$ [41] and an open porosity of $0.53 \%$.

Santa Caterina di Pittinuri limestone is a biomicrite obtained from a former quarry (ex Cava Flore) around Cuglieri (OR) in western Sardinia, Italy [42]. Its many microfossils $(<300 \mu \mathrm{m})$ lie in a cryptocrystalline matrix also housing iron oxide gels [41]. Its open porosity is $26.44 \%$.

\subsection{Sample preparation and accelerated ageing}

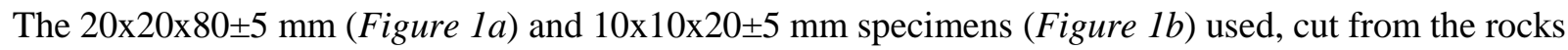
chosen with a circular saw at $120 \mathrm{rpm}$, were exposed to thermal stress to accelerate ageing and induce the decay required. In this study, the artificial ageing procedure [43] consisted in heating the samples at $600{ }^{\circ} \mathrm{C}$ in a muffle furnace for $7 \mathrm{~h}$ to substantially reduce mechanical strength [41], comfortably below the $800{ }^{\circ} \mathrm{C}$ thermal decomposition threshold for calcite [44].

\subsection{Consolidant}

The Sigma-Aldrich (CAS 215996, >98 \% pure) diammonium hydrogen phosphate (DAP) used was dissolved in water to a concentration of $3 \mathrm{M}$. When applied to calcium carbonate-high stones, this precursor generates calcium phosphates, with hydroxyapatite (HAP) as the most insoluble phase [5]. In addition to HAP, however, other more soluble and less readily identified phases may also form [30], including octacalcium phosphate (OCP), dicalcium phosphate dihydrate (DCPD or brushite) and anhydrous dicalcium phosphate (ADCP).

\subsection{Consolidation treatments tested}

The surfaces of 12 specimens, three limestone and three marble prisms of each of the two sizes described in section 2.2, were treated.

Earlier studies $[5,14,45,46]$ defined laboratory parameters including treatment duration, solution concentration and operating temperature. Concentration and application time were observed to affect

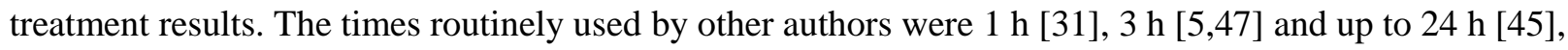
while concentration ranged from $0.1 \mathrm{M}$ to $3 \mathrm{M}$. DAP may be spiked with calcium additives to favour calcium phosphate or other phase formation $[15,16,46,48]$.

Based on earlier experiments [49], here the experimental design envisaged applying the solution by brushing it onto the specimens, immersing them in the solution or packing a poultice around them (hereafter, brushing, immersion, poultice packing). A $3 \mathrm{M}$ DAP solution was used with water as the solvent. The samples were in contact with the product for $2 \mathrm{~h}$ at ambient temperature $\left(25 \pm 2{ }^{\circ} \mathrm{C}\right)$ in an environment with a relative humidity of $35 \pm 5 \%$.

The consolidants were applied for $2 \mathrm{~h}$, the time needed for capillary sorptivity to stabilise in the thermally aged samples (Figure 2). Prior to treatment, the specimens were heated in a kiln at $50 \pm 5^{\circ} \mathrm{C}$ to a constant mass. After the $2 \mathrm{~h}$ in which the solution was in contact with the specimens, all the surfaces were rinsed five times with $80 \mathrm{~mL}$ of distilled water.

Brushing: the DAP solution was brushed onto all sides of the specimen until it was no longer absorbed by 
the stone. The marble required three consecutive brush strokes on each side of the specimen and a second coat of three consecutive strokes $1 \mathrm{~min}$ after the last stroke in the first coat. In the more porous limestone, a total of three 8-stroke coats were needed on each side of the specimen to reach saturation, deemed to have been attained when the surface turned glossy and the substrate ceased to absorb more product.

The coated specimens were wrapped and kept in Parafilm ${ }^{\circledR}$ for $2 \mathrm{~h}$ and subsequently unwrapped, patted with blotting paper, weighed and rinsed.

Immersion: the specimens were immersed in $150 \mathrm{~mL}$ of aqueous DAP solution in a Parafilm ${ }^{\circledR}$ sealed beaker to hinder evaporation. After $2 \mathrm{~h}$, they were removed from the beaker, tapped with blotting paper, weighed and rinsed.

Poultice packing: $12 \mathrm{~g}$ of Arbocell $\mathrm{BC} 200^{\circledR}$ powdered cellulose were mixed with $70 \mathrm{~mL}$ of $3 \mathrm{M}$ DAP solution until a uniformly blended, mouldable paste was obtained. The specimens were then packed in the resulting $5 \pm 2 \mathrm{~mm}$ thick mass and wrapped in Parafilm ${ }^{\circledR}$. After $2 \mathrm{~h}$, the poultice packs were removed and the specimens tapped with blotting paper, weighed and rinsed.

All specimens were stabilised at $25 \pm 5{ }^{\circ} \mathrm{C}$ and $30 \pm 5 \%$ relative humidity for 10 days prior to testing and analysis.

\subsection{Analytical methods}

Product absorption estimates: The amount of DAP absorbed was determined by weighing the specimens before and after application of the solution. The variation in weight of the treated samples relative to their dry weight was found immediately after the consolidant was applied. The amount of active solution was calculated by weighing the specimens 10 days after application, when sample weight had stabilised.

Scanning electron microscopy (SEM-EDX): Consolidant penetration depth was determined on crosssections of the specimens cut at around $10 \mathrm{~mm}$ (Figure 1c) from the top of the original sample (20x20x80 $\mathrm{mm}$ ) and sputter-coated with graphite using a BALZERS MED 010 unit. Phosphorus (Pko) distribution profiles and maps were drawn to establish treatment penetration depth based on analyses conducted on a JEOL JSM 6400 scanning electron microscope (SEM) fitted with a $133 \mathrm{eV}$ Oxford-Link Pentafet energydispersive X-ray (EDX) qualitative elemental analyser and a thermoionic electron gun with a tungsten filament and secondary electron detector.

Mercury intrusion porosimetry (MIP): $\mathrm{Hg}$-accessible porosity, mean pore size and percentage of macro

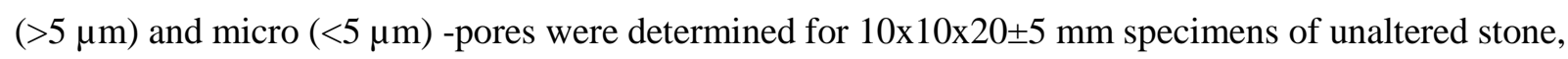
stone exposed to thermal shock [41] and the DAP-brushed, immersed and poultice-packed stone specimens (Figure 1b) on a Micromeritics AutoPore IV 9520 porosimeter [50].

Ultrasonic pulse velocity (UPV): was measured with a CNS Electronics PUNDIT analyser (precision \pm 0.1 $\mu \mathrm{s})$, using $1 \mathrm{MHz}$ transducers with a contact surface of $11.82 \mathrm{~mm}$ in diameter and a rubber membrane as the coupling medium. Transmission was measured directly with 10 consecutive readings (subsequently averaged) in different positions (Figure 1a) along the three orthogonal axes (sample size 20x20x80 mm) for each type of material and consolidant application technique, before and after treatment.

The anisotropy index for each specimen was found before and after DAP treatment by summing the dM\% and $\mathrm{dm} \%$ indices [51] and $\mathrm{dMm} \%$ [52], from the following equations: 
$\mathrm{dM}=[1-(2 \mathrm{UPV}$ min $/($ UPVmean + UPVmax $))] \times 100(\%)$

$\mathrm{dm}=[(2 \times(\mathrm{UPV} m a x-\mathrm{UPV}$ mean $) /(\mathrm{UPV}$ mean $+\mathrm{UPVmax})] \times 100(\%)$

$\mathrm{dMm}=\mathrm{dM}+\mathrm{dm}$

where UPVmin is the minimum, UPVmean the mean and UPVmax the maximum values measured in the three spatial directions.

The ratio between the UPV for the unaltered sample fresh from the quarry (Vpi) and the value for the artificial damaged stone ( $\mathrm{Vpm}$ ) [53] was used to determine the alteration index (Ia) from the equation $\mathrm{Ia}=\mathrm{Vpm} / \mathrm{Vpi} \mathrm{x} 100$. The value was subsequently compared to the results after consolidation treatment.

Young's modulus (Ed): The ultrasonic pulse velocity data were used to determine the dynamic Young's modulus (Ed) from the equation $\mathrm{Ed}=\rho \cdot \mathrm{UPV}^{2}$, where UPV is the mean value of all the readings taken in each specimen and $\rho$ the vacuum density expressed in $\mathrm{kg} / \mathrm{m}^{3}$ [54]. That indirect approach delivered information on the change in mechanical properties after applying the consolidant.

Colour parameters: the colour changes in the specimens treated with the consolidant (DAP) were measured under standard illuminant D65 on a Spectra Magic NX software-compatible Minolta CM-700d spectrophotometer with an $8 \mathrm{~mm}$ diameter measuring area and a spectral range of 400 to $700 \mathrm{~nm}$. CIE LAB colour parameters $[55,56]$ determined were defined as follows: $\mathrm{L}^{*}$ (lightness), with values from 0 (black) to 100 (white); $\mathrm{a}^{*}$ (red/green axis), in which red is the positive and green the negative axis; and $\mathrm{b}^{*}$ (yellow/blue axis), in which yellow is the positive axis and blue the negative axis.

The overall post-treatment colour alteration generated in the stone $\left(\Delta \mathrm{E}^{*}\right)$ was found by entering the variations in $\mathrm{L}^{*}, \mathrm{a}^{*}$ and $\mathrm{b}^{*}$ in the equation: $\Delta \mathrm{E}^{*}=\left[\left(\Delta \mathrm{L}^{*}\right)^{2}+\left(\Delta \mathrm{a}^{*}\right)^{2}+\left(\Delta \mathrm{b}^{*}\right)^{2}\right]^{0.5}[57]$.

Three colour measurements were made on each side of the specimens; the values shown are the respective mean and standard deviations.

Roughness parameters: roughness is one of the characteristics of the physical surface of materials which, when exposed to weathering, may vary. It was measured to ascertain whether part of the consolidant was retained on the stone surface and whether that change in roughness might induce colour change in the treated materials.

The stone samples treated with differently applied consolidants were analysed for roughness indices and topography using a TRACEit (Innowep) three-dimensional roughness meter operating at a resolution of 2.5 $\mu \mathrm{m}$ along the three Cartesian axes. The meter's optical measuring unit was connected to a laptop computer running software specifically designed to capture and process the images transmitted by the measuring unit. The measuring area used was $25 \mathrm{~mm}^{2}$. The topography of the area measured and the roughness parameters for each treated specimen were determined from 500 profiles recorded in the $\mathrm{X}$ and $\mathrm{Y}$ directions.

$\mathrm{Rz}$, the mean difference in height between the five highest peaks and five lowest valleys along the profiles measured, was used to compare the variation in roughness [58]. Three areas were measured on each specimen before and after applying the consolidant and the respective mean and standard deviation values were found and the mean 3D roughness diagrams drawn. 


\section{RESULTS}

The amount of DAP absorbed by the specimens under each application procedure and the amount of active product retained in the specimens are keys to evaluating consolidant behaviour. Table 1 shows that much more DAP was absorbed by the limestone than by the marble due to the difference in porosity between the two. The amount of DAP absorbed varied little from one application to the next, although the active residue was never over $0.5 \mathrm{wt} \%$ in marble, compared to $11.0 \mathrm{wt} \%$ to $13.6 \mathrm{wt} \%$ in limestone.

Consolidant absorption was highest in marble with brushing and in limestone with poultice packing.

This measure afforded no information on product distribution, however, for the DAP could have remained on the surface without penetrating the stone.

Table 1. Weight gain (g), product absorption and \% of active product after brushing, immersion and poultice packing

\begin{tabular}{cccc|ccc}
\hline & \multicolumn{3}{c|}{ MARBLE } & \multicolumn{3}{c}{ LIMESTONE } \\
\cline { 2 - 7 } & Brush & Immersion & Poultice & Brush & Immersion & Poultice \\
\hline Weight gain $(\mathbf{g})$ & 1.20 & 1.15 & 1.12 & 11.77 & 11.73 & 11.89 \\
\hline $\begin{array}{c}\text { Product } \\
\text { absorption } \\
\left(\mathbf{g} / \mathbf{m}^{\mathbf{2}}\right)\end{array}$ & 162 & 154 & 153 & 1579 & 1533 & 1590 \\
\hline $\begin{array}{c}\text { Active residue } \\
(\%)\end{array}$ & 0.44 & 0.37 & 0.50 & 12.59 & 11.08 & 13.66 \\
\hline
\end{tabular}

Elemental analysis and product distribution was determined with SEM-EDX analysis on specimens prepared as depicted in Figure 1c. The resulting phosphorous $(\mathrm{PK} \alpha)$ profiles and distribution maps are shown in Figure 3.

Product distribution was found to differ with the application technique used and the phosphorus distribution and concentration profiles to vary as shown in Table 2.

In brushed marble the phosphorus distribution profile was uneven, with maximum deposition at depths of $0.2 \mathrm{~mm}$ to $0.5 \mathrm{~mm}$ and a less intense presence up to $5 \mathrm{~mm}$. Penetration was more even when specimens were immersed in the consolidant, with deposition greatest at $0.3 \mathrm{~mm}$ and $\mathrm{PK} \alpha$ declining to naught at $5 \mathrm{~mm}$. In poultice-packed samples the consolidant penetrated to a depth of $5 \mathrm{~mm}$, with peak PK $\alpha$ intensity highest in the first millimetre.

When the consolidant was brushed onto limestone peak PK $\alpha$ intensity was reached at a depth of $1 \mathrm{~mm}$ while phosphorus was detected at up to $10 \mathrm{~mm}$ (Figure 3). After immersion, maximum deposition was observed at a depth of $1.5 \mathrm{~mm}$, although phosphorus was unevenly present up to $10 \mathrm{~mm}$.Phosphorus concentration maximum deposition (with intensities of $>90$ ) was found at $1 \mathrm{~mm}$ in the poultice-packed specimens at a maximum intensity of 40 . 
Table 2. Post-treatment penetration depth, phosphorus distribution profile and peak Pka intensity (SEM-EDX findings)

\begin{tabular}{|c|c|c|c|c|c|c|}
\hline \multicolumn{7}{|c|}{ MARBLE } \\
\hline & \multicolumn{2}{|c|}{ Brush } & \multicolumn{2}{|c|}{ Immersion } & \multicolumn{2}{|r|}{ Poultice } \\
\hline $\begin{array}{c}\text { Penetration } \\
\text { depth }\end{array}$ & $\begin{array}{c}\text { Peak Pko } \\
\text { intensity }\end{array}$ & $\begin{array}{c}\text { Phosphorus } \\
\text { distribution } \\
\text { profile }\end{array}$ & $\begin{array}{l}\text { Peak Pka } \\
\text { intensity }\end{array}$ & $\begin{array}{c}\text { Phosphorus } \\
\text { distribution profile }\end{array}$ & $\begin{array}{l}\text { Peak Pka } \\
\text { intensity }\end{array}$ & $\begin{array}{c}\text { Phosphorus } \\
\text { distribution profile }\end{array}$ \\
\hline 0 - 2 mm & 36 & even (max. dep.) & 24 & even (max. dep.) & 17 & even (max. dep.) \\
\hline $2-5 \mathrm{~mm}$ & $<5$ & uneven & $<5$ & even & $5-10$ & even \\
\hline $5-10 \mathrm{~mm}$ & - & - & - & - & - & - \\
\hline \multicolumn{7}{|c|}{ LIMESTONE } \\
\hline & \multicolumn{2}{|c|}{ Brush } & \multicolumn{2}{|c|}{ Immersion } & \multicolumn{2}{|r|}{ Poultice } \\
\hline $\begin{array}{c}\text { Penetration } \\
\text { depth }\end{array}$ & $\begin{array}{c}\text { Peak Pko } \\
\text { intensity }\end{array}$ & $\begin{array}{c}\text { Phosphorus } \\
\text { distribution } \\
\text { profile }\end{array}$ & $\begin{array}{l}\text { Peak Pka } \\
\text { intensity }\end{array}$ & $\begin{array}{c}\text { Phosphorus } \\
\text { distribution profile }\end{array}$ & $\begin{array}{l}\text { Peak Pka } \\
\text { intensity }\end{array}$ & $\begin{array}{c}\text { Phosphorus } \\
\text { distribution profile }\end{array}$ \\
\hline $0-2 \mathrm{~mm}$ & 14 & even (max. dep.) & 44 & even (max. dep.) & 91 & even (max. dep.) \\
\hline $2-5 \mathrm{~mm}$ & $>5$ & uneven & $>10$ & uneven & $>10$ & even \\
\hline $5-10 \mathrm{~mm}$ & $1-2$ & uneven & $5-30$ & even & $5-40$ & even \\
\hline
\end{tabular}

The UPV readings recorded in both marble and limestone were higher for all the treated than for the artificially damaged specimens (altered), irrespective of the application method (Table 3). The rises recorded after DAP application were greater as a rule in marble than in limestone, a finding attributable to the differential effect of thermal ageing on the two materials. As decay in the form of considerable fracturing [41] was more intense in marble, its successful repair by the DAP solution translated into greater relative improvement in the UPV values.

Similar rises ( $80 \%$ to $85 \%$ ) in UPV were observed in marble for all three types of application, although the absolute values were considerably lower than in the unaltered quarry stone (Table 3).

In limestone, immersion raised mean UPV most ( $+27 \%)$, followed by brushing $(+25 \%)$ and poultice packing $(+21 \%)$ (Table 3). After consolidant application with all three methods, the values observed were very near the UPV readings for the original quarry limestone.

Table 3. Variation in ultrasonic propagation velocity (UPV), anisotropy index (dM/dm), total anisotropy (dMm) and alteration index (Ia) before and after applying the consolidant

\begin{tabular}{|c|c|c|c|c|c|c|c|c|c|c|c|c|}
\hline & & \multicolumn{5}{|c|}{ MARBLE } & \multicolumn{6}{|c|}{ LIMESTONE } \\
\hline & $\begin{array}{l}\mathrm{UPV} \\
{[\mathrm{m} / \mathrm{s}]}\end{array}$ & $\begin{array}{c}\Delta_{\mathrm{UPV}} \\
{[\%]}\end{array}$ & $\begin{array}{l}\mathrm{dM} \\
{[\%]}\end{array}$ & $\begin{array}{l}\mathrm{dm} \\
{[\%]}\end{array}$ & $\begin{array}{c}\mathrm{dMm} \\
{[\%]}\end{array}$ & $\begin{array}{c}\mathrm{Ia} \\
{[\%]}\end{array}$ & $\begin{array}{l}\mathrm{UPV} \\
{[\mathrm{m} / \mathrm{s}]}\end{array}$ & $\begin{array}{c}\Delta_{\mathrm{UPV}} \\
{[\%]}\end{array}$ & $\begin{array}{l}\mathrm{dM} \\
{[\%]}\end{array}$ & $\begin{array}{l}\mathrm{dm} \\
{[\%]}\end{array}$ & $\begin{array}{r}\mathrm{dMm} \\
{[\%]}\end{array}$ & $\begin{array}{l}\mathrm{Ia} \\
{[\%]}\end{array}$ \\
\hline Quarry & $5522 \pm 68$ & -- & 1.8 & 1.4 & 3.2 & - & $2865 \pm 51$ & -- & 2.9 & 1.0 & 3.9 & - \\
\hline $\begin{array}{l}\text { Artificially } \\
\text { aged }\end{array}$ & $1660 \pm 117$ & -70 & 6.6 & 11.2 & 17.8 & 30 & $2213 \pm 26$ & -23 & 1.9 & 0.8 & 2.7 & 77 \\
\hline Brush & $2998 \pm 125$ & 81 & 5.5 & 5.2 & 10.7 & 54 & $2786 \pm 141$ & 25 & 6.7 & 6.1 & 12.8 & 97 \\
\hline Immersion & $2986 \pm 86$ & 80 & 4.9 & 0.6 & 5.5 & 54 & $2804 \pm 63$ & 27 & 2.2 & 3.7 & 5.9 & 98 \\
\hline Poultice & $3063 \pm 69$ & 85 & 3.2 & 2.4 & 5.6 & 55 & $2667 \pm 160$ & 21 & 5.9 & 9.6 & 15.5 & 93 \\
\hline
\end{tabular}

Decay in marble prompted a rise in its anisotropy (Table 3), with a dMm value of $17.8 \%$ (up from $3.2 \%$ in the quarry stone). After application of the consolidant, the indices declined to $10.7 \%$ for brushing and around $5.5 \%$ with immersion and poultice packing. The latter yielded the best results, with $\mathrm{dM}$ and $\mathrm{dm}$ indices closest to those observed for the pre- decay quarry stone. No prominent changes in limestone 
anisotropy were induced by decay (Table 3). Application of the consolidant raised the indices to $12.8 \%$ with brushing and around $5.9 \%$ with immersion and $15.5 \%$ with poultice packing. Deeper product penetration in the limestone might favour the formation of a distinct plane of anisotropy between the treated surface and untreated inner areas, which would explain the higher values observed for brushing and poultice packing.

After consolidant application, the alteration index (Ia) obtained in the treated marble specimens ranged from $54 \%$ to $55 \%$ with all three application methods, compared to $30 \%$ in the decayed stone (Table 3). The treated limestone values, at $93 \%$ to $98 \%$, were very near the unaltered quarry stone index.

The dynamic Young's modulus values in Table 4 show that in relative terms, ageing affected the mechanical properties less in limestone than in marble, where cracking was more intense. Although Ed rose in marble with all the consolidant application methods, improvement was greatest after poultice packing. The $460 \%$ increase over the absolute pre-treatment value of $5.06 \mathrm{GPa}$ did not suffice to recover the Ed observed in the quarry stone. Decay was less accentuated in limestone. Brushing and poultice packing yielded Ed values nearly as high as in the stone prior to accelerated ageing.

Table 4. Dynamic Young's modulus (Ed) in quarry stone and artificially aged stone before and after applying consolidant

\begin{tabular}{lcc|cc}
\hline & \multicolumn{2}{c|}{ MARBLE } & \multicolumn{2}{c}{ LIMESTONE } \\
\cline { 2 - 5 } & Ed (GPa) & $\boldsymbol{\Delta}_{\text {Ed }}[\%]$ & Ed (GPa) & $\boldsymbol{\Delta}_{\text {Ed }[\%]}$ \\
\hline Quarry & 82.44 & --- & 13.07 & -- \\
\hline $\begin{array}{l}\text { Artificially } \\
\text { aged }\end{array}$ & 5.06 & -94 & 7.43 & -43 \\
Brush & 16.85 & 333 & 12.75 & 172 \\
\hline Immersion & 21.35 & 422 & 11.53 & 155 \\
\hline Poultice & 23.35 & 461 & 12.78 & 172 \\
\hline
\end{tabular}

Consolidation treatment tended to reduce porosity and mean pore size. After immersion however, the porosity accessible to mercury in the marble remained unchanged, whereas it declined by $9 \%$ after brushing and $3 \%$ after poulticing (Table 5). Despite the scant decline in porosity, the consolidant altered the pore structure, reducing mean pore size from $0.82 \mu \mathrm{m}$ in the decayed marble to values of around $0.60 \mu \mathrm{m}$ in the immersed and poultice-packed specimens. Brushing induced a smaller decline (to $0.75 \mu \mathrm{m}$ ), although the percentage of pores in the $1 \mu \mathrm{m}$ to $10 \mu \mathrm{m}$ interval slid, the percentage of micropores in the consolidated specimens was not significantly altered. Immersion induced a rise in the percentage of micropores, primarily in the $0.01 \mu \mathrm{m}$ to $0.1 \mu \mathrm{m}$ range, and a drastic decline in pores over $100 \mu \mathrm{m}$ in diameter, with the proportion of micropores rising from $54 \%$ to $95.7 \%$ (Table 5 and Figure 4). Poultice packing raised the micropore fraction to $81.6 \%$ due to the increase in the volume of pores ranging in size from $0.01 \mu \mathrm{m}$ to $1 \mu \mathrm{m}$ and a decline in the proportion of larger size pores. The changes in pore structure with the various application methods are depicted in Figure 4.

In limestone the consolidant reduced the accessible porosity by $9 \%$ from the $30.37 \%$ observed in the decayed stone to values of around $27.5 \%$ in the brush- or immersion-consolidated specimens. Those values were very close to quarry stone porosity $(26.44 \%$, Table 5$)$.

Poultice packing lowered porosity to $29.44 \%$ for a decline of around $3 \%$ relative to the altered limestone. The consolidation treatments changed pore size distribution in the limestone specimens, from the bimodal 
( $0.7 \mu \mathrm{m}$ to $5 \mu \mathrm{m}$ and $7 \mu \mathrm{m}$ to $9 \mu \mathrm{m})$ pattern observed in the altered stone to a unimodal $(0.4 \mu \mathrm{m}$ to $5 \mu \mathrm{m})$ distribution in the consolidated stone, with a higher concentration in the $3 \mu \mathrm{m}$ to $5 \mu \mathrm{m}$ interval in the poultice-packed specimens (Figure 4). The inference is that the DAP treatment tended to close the largest pores (fissure porosity with voids of over $400 \mu \mathrm{m}$ ) generated by the thermal treatment used to age the marble. Further to the data in Table 5, the rise in macropores $(>5 \mu \mathrm{m})$ was greatest when the consolidant was applied with a brush, after which the $100 \mu \mathrm{m}$ to $400 \mu \mathrm{m}$ fraction disappeared (Figure 4).

Table 5. Porosimetry parameters in marble and limestone consolidated with different techniques (md: mean pore diameter)

\begin{tabular}{lcccc|cccc}
\hline & \multicolumn{3}{c|}{ MARBLE } & \multicolumn{4}{c}{ LIMESTONE } \\
\hline & Porosity & $\mathrm{md}$ & \multicolumn{2}{c|}{ Pore size range } & Porosity & md & Pore size range \\
\hline & $(\%)$ & $(\mu \mathrm{m})$ & $\%>5 \mu \mathrm{m}$ & $\%<5 \mu \mathrm{m}$ & $(\%)$ & $(\mu \mathrm{m})$ & $\%>5 \mu \mathrm{m}$ & $\%<5 \mu \mathrm{m}$ \\
\hline Quarry & 0.53 & 0.27 & 46.0 & 54.0 & 26.44 & 0.53 & 7.0 & 93 \\
\hline $\begin{array}{l}\text { Artificially } \\
\text { aged }\end{array}$ & 2.37 & 0.82 & 19.0 & 81.0 & 30.37 & 0.87 & 15.8 & 84.2 \\
\hline Brush & 2.15 & 0.75 & 32.5 & 67.5 & 27.53 & 0.28 & 11.4 & 88.6 \\
\hline Immersion & 2.38 & 0.64 & 4.3 & 95.7 & 27.58 & 0.30 & 13.6 & 86.4 \\
\hline Poultice & 2.29 & 0.63 & 18.4 & 81.6 & 29.44 & 0.33 & 12.5 & 87.5 \\
\hline
\end{tabular}

Application of the consolidant did not change the colour relative to the unaltered marble, with differences in $\Delta \mathrm{E}^{*}$ values of no more than 5 units (Table 6). Poultice packing delivered the smallest variation $\left(\Delta \mathrm{E}^{*}=0.55\right)$. The findings for limestone differed, with $\Delta \mathrm{E}^{*}=11$ after poultice packing, $\Delta \mathrm{E}^{*}=9$ after brushing and $\Delta \mathrm{E}^{*}=$ 4 after immersion.

Table 6. Mean colour parameters (and standard deviation) and overall colour change $\left(\Delta \mathrm{E}^{*}\right)$ after consolidation treatment

\begin{tabular}{ccccccc}
\hline & Parameter & Quarry & $\begin{array}{c}\text { Artificially } \\
\text { aged }\end{array}$ & Brush & Immersion & Poultice \\
\hline & $\mathrm{L}^{*}$ & $86.5 \pm 0.3$ & $93.9 \pm 0.2$ & $91.4 \pm 1.2$ & $92.6 \pm 0.1$ & $93.5 \pm 0.1$ \\
\cline { 2 - 7 } MARBLE & $\mathrm{a}^{*}$ & $-0.6 \pm 0.0$ & $0.1 \pm 0.1$ & $0.2 \pm 0.1$ & $0.09 \pm 0.1$ & $0.01 \pm 0.0$ \\
\cline { 2 - 7 } & $\mathrm{b}^{*}$ & $0.2 \pm 0.2$ & $3.3 \pm 0.1$ & $4.1 \pm 0.3$ & $4.2 \pm 0.4$ & $3.7 \pm 0.2$ \\
\cline { 2 - 7 } & $\mathbf{\Delta E}^{*}$ & - & - & $\mathbf{2 . 6 4}$ & $\mathbf{1 . 6 0}$ & $\mathbf{0 . 5 5}$ \\
\hline \multirow{2}{*}{ LIMESTONE } & $\mathrm{L}^{*}$ & $87.6 \pm 0.1$ & $77.8 \pm 0.1$ & $71.9 \pm 0.6$ & $75.9 \pm 1.1$ & $68.2 \pm 1.1$ \\
\cline { 2 - 7 } & $\mathrm{a}^{*}$ & $1.5 \pm 0.1$ & $2.0 \pm 0.3$ & $0.9 \pm 0.1$ & $1.4 \pm 0.1$ & $1.5 \pm 0.4$ \\
\cline { 2 - 7 } & $\mathrm{b}^{*}$ & $10.2 \pm 0.9$ & $8.7 \pm 0.6$ & $2.0 \pm 0.6$ & $5.4 \pm 0.2$ & $3.3 \pm 0.3$ \\
\cline { 2 - 7 } & $\mathbf{\Delta E}^{*}$ & - & - & $\mathbf{8 . 9 2}$ & $\mathbf{3 . 7 9}$ & $\mathbf{1 1 . 0 2}$ \\
\hline
\end{tabular}

Marble roughness was altered by the consolidation treatments, irrespective of the application method (Table 7). It was reduced most by brushing: in the $X$ direction it declined by nearly 30 relative to the damaged stone, while in the $\mathrm{Y}$ direction the decrease was less than $20 \%$. A similar pattern was observed for immersion (25\% in the $\mathrm{X}$ and $15 \%$ in the $\mathrm{Y}$ direction). Surface roughness was altered least by poultice packing, which induced a slight $(6 \%)$ reduction in the $\mathrm{X}$ direction and no significant change in the $\mathrm{Y}$ direction. 
Table 7. Marble and limestone roughness parameters before and after consolidant application with different techniques

\begin{tabular}{ccccc}
\hline & \multicolumn{2}{c}{ MARBLE } & \multicolumn{2}{c}{ LIMESTONE } \\
\hline & $\mathbf{X}$ & $\mathbf{Y}$ & $\mathbf{X}$ & $\mathbf{Y}$ \\
\hline Quarry & $9.24 \pm 0.72$ & $9.31 \pm 0.10$ & $29.16 \pm 2.61$ & $31.36 \pm 2.52$ \\
\hline Artificial damaged & $8.12 \pm 0.41$ & $7.46 \pm 0.31$ & $34.11 \pm 3.91$ & $34.67 \pm 4.41$ \\
\hline Brush & $5.78 \pm 1.87$ & $6.04 \pm 1.98$ & $14.88 \pm 2.29$ & $15.35 \pm 2.11$ \\
$\Delta[\%]$ & -28.82 & -19.14 & -56.37 & -55.74 \\
\hline Immersion & $6.10 \pm 1.91$ & $6.47 \pm 2.38$ & $29.22 \pm 2.40$ & $30.10 \pm 3.03$ \\
$\Delta[\%]$ & -24.91 & -13.31 & -14.34 & -13.17 \\
\hline Poultice & $7.60 \pm 4.46$ & $7.46 \pm 3.73$ & $14.62 \pm 1.83$ & $14.69 \pm 2.10$ \\
$\Delta[\%]$ & -6.41 & -0.04 & -57.12 & -57.62 \\
\hline
\end{tabular}

The increase in limestone roughness induced by thermal ageing tended to decline with the consolidation treatments tested. Immersion led to the smallest variation, yielding roughness similar to the original value in the unaltered stone, whilst the other two methods, brushing and poultice packing, prompted a substantial decline of around $55 \%$ relative to the artificial damaged limestone.

The change in surface roughness in marble is distinctly visible in Figure 5, where the decay in the stone is clearly visible [41]. The consolidant reduced the roughness aligned with the Y-axis, with poultice packing (Figure 5e) delivering roughness most similar to that of the unaltered marble (Figure 5a). In limestone, roughness was varied most by brushing and poultice packing.

\section{DISCUSSION}

The results of the analyses conducted differed not only by application method, but also by stone type, due to the intrinsic characteristics of the starting materials studied, i.e., porosity, pore size distribution, alteration index and capillary sorptivity.

DAP was detected to a depth of $5 \mathrm{~mm}$ in marble and $10 \mathrm{~mm}$ in limestone with all three application techniques. When brushed onto marble and limestone, DAP concentrated primarily on the surface, with the highest concentration found up to $0.5 \mathrm{~mm}$ in marble and up to $10 \mathrm{~mm}$ in the more porous limestone, although the distribution profile was uneven in the latter.

With immersion, maximum deposition was maintained to depths of $1 \mathrm{~mm}$ in marble and $1.5 \mathrm{~mm}$ in limestone, although deposition was uneven in the latter up to $5 \mathrm{~mm}$ and more even between $5 \mathrm{~mm}$ and $10 \mathrm{~mm}$.

In poultice-packed specimens the profile was even up to a depth of $5 \mathrm{~mm}$ in marble and $10 \mathrm{~mm}$ in limestone. Maximum deposition and intensity were observed in the outermost millimetre in both materials.

Those findings are consistent with the depths of $2 \mathrm{~mm}$ in marble [52] and under $10 \mathrm{~mm}$ in limestone reported by other authors $[5,16,45]$. Resolution differs with the techniques used to measure penetration depth. XRF, micro-Raman and FTIR, not applied in this study, have been reported to detect depths of $18 \mathrm{~mm}$ after brushing and $25 \mathrm{~mm}$ after poultice packing [13] with the same $3 \mathrm{M}$ solution although with longer contact times.

The shallower penetration observed for brushing in limestone might have been the outcome of rapid evaporation, which would prevent product ingress into the specimen, leaving part on the surface. That 
method also distributed the product less evenly, whilst penetration was more homogeneous with immersion and poultice packing. In immersion, product penetration was hindered by the air entrained in the pore structure that could not be displaced. Both problems were eluded with poultice packing, for slower treatment ingress obstructed evaporation, enabling the DAP solution to penetrate more deeply, with a concomitantly higher percentage of active residue than with the other two methods. The deeper penetration of consolidant in limestone raised anisotropy, which was greatest with poultice packing $(\mathrm{dMm} \%=15.5)$. Application of the consolidant to limestone with any of the three methods led to UPV values close to those observed in the unaltered stone. The product was less effective in the more severely decayed marble, which was consolidated best by poultice packing.

Consolidant effectiveness in terms of stone mechanical properties was assessed by analysing the variations in both the ultrasonic measurements of the dynamic module (Ed) and in UPV. Artificial ageing in marble lowered Ed by $94 \%$ and in limestone by $43 \%$ (Table 3). In this as in other studies [36], treatment was observed to attenuate that decline. Effectiveness was proportionally greater in marble, particularly when a poultice was used, inasmuch as it was more severely decayed than limestone, although quarry Ed and UPV values were not attained. In limestone in contrast, they were very close to the original values.

The consolidant reduced porosity in the altered marble and limestone slightly, and nearly insignificantly when applied with poultices. Marble pore structure was improved most with brushing, which induced a lower percentage of micropores than the other methods, favouring greater resistance to saline environments or frost. Immersion failed to lower porosity but reduced pore size, rendering the stone more compact although perhaps also weakening its resistance to salt crystallisation or frost. Other authors detected no major change in pore size distribution [14]. In limestone the percentage of micropores declined irrespective of the application method, although in the poultice-packed stone the mode was more sharply defined and shifted toward larger pore diameters than in the materials treated with the other two methods (Figure 4). The fraction of pores under $0.1 \mu \mathrm{m}$ was observed to rise in limestone with all three methods $[6,53]$.

Inasmuch as product surface concentration was higher with brushing, that method reduced roughness in both materials, whereas packing marble in a poultice delivered roughness values closest to those observed in the pre-treated (quarry and artificial damaged) material. In limestone immersion modified roughness the least relative to the non-consolidated stone.

Marble underwent no significant colour change when treated. Variation was greatest with brushing, perhaps due to the surface concentration of the product. The values found were consistent with those of other authors $[36,45,54]$. Poultice packing induced the greatest colour change in limestone, resulting in $\Delta \mathrm{E}^{*}=11$ that may advise against using the method with this stone. Earlier studies detected smaller changes in limestone, with values no higher than $5[6,13,53]$. Prior authors have tentatively associated the $\Delta \mathrm{E}^{*}$ values observed for other materials with product concentration, application procedures and types of stone studied [62,63].

In marble, roughness declined most with brushing (Table 7), where scant penetration and higher consumption $\left(162 \mathrm{~g} / \mathrm{m}^{2}\right)$ suggested that part of the consolidant was retained on the surface, resulting in a more significant change in colour than with the other application techniques. Roughness declined most in brushed and poultice-packed limestone, the specimens where colour change was most conspicuous (at 8.92 and 11.02, respectively), inferring that roughness affects colour determination (Benavente et al., 2003). 


\section{CONCLUSIONS}

Application procedures have been shown to be a prominent variable in the effectiveness of consolidation treatments for marble and limestone (Figure 6). An aqueous DAP solution improved the parameters analysed with different techniques. Poultice packing was the method found to be best suited to marble. The procedure that delivered the best results in limestone was immersion, although for obvious practical reasons its use is limited to small heritage elements and must be ruled out for large building units such as façades. With poultice packing, which would also be appropriate for limestone, product penetration is deeper than with brushing, although this method is subject to a major drawback: the significant colour change induced in the consolidated limestone. While penetration is shallower and surface accumulation greater with brushing, that technique yields better results for the other parameters analysed. Poulticing and to a lesser extent brushing are the two most suitable procedures for improving the carbonate substrates explored in this study.

From a practical perspective, brushing is indisputably more straightforward for in situ applications. Its drawbacks include the lack of control of the amount of product applied and its evaporation due to environmental conditions at the time of application, along with its lesser penetration power, particulars that are more readily controlled with poultice packing. Application is also fairly convenient with this latter method, even on slanted surfaces to which cellulose adheres readily. Moreover, poultices can be fully removed after application, although the method is more costly than brushing.

\section{Acknowledgements}

Funding for this study was furnished by the Autonomous Region of Madrid's Geomateriales 2 and Top Heritage Programme (S2013/MIT-2914 and S2018/NMT-4372). The technical assistance provided by Applied Petrology for Heritage Conservation, Research Group 921349, and the use of analytical facilities at the Geosciences Institute's Petrophysical Laboratory (National Research Council, CSIC-Complutense University of Madrid, UCM) and the UCM's National Electron Microscopy Centre are gratefully acknowledged.

Special thanks to Dr. Paola Meloni, the scientific director of the Bonaria Laboratory, University of Cagliari. Manuscript edited by Margaret Clark, professional translator and English language science editor.

\section{REFERENCES}

[1] A.L. Boskey, A.S. Posner, Formation of hydroxyapatite at low supersaturation, J. Phys. Chem. 80.1 (1976) 40-45.

[2] H.H.K. Xu, J.B. Quinn, Calcium phosphate cement containing resorbable fibers for short- term reinforcement and macroporosity, Biomaterials. 23 (2002) 193-202.

[3] C. Combes, C. Rey, Amorphous calcium phosphates: Synthesis, properties and uses in biomaterials, Acta Biomater. 6 (2010) 3362-3378.

[4] M. Tanaka, H. Haniu, T. Kamanaka, T. Takizawa, A. Sobajima, K. Yoshida, K. Aoki, M. Okamoto, H. Kato, N. Saito, Physico-chemical, in vitro, and in vivo evaluation of a 3D unidirectional porous hydroxyapatite scaffold for bone regeneration, Materials 10 (2017) 33.

[5] M. Matteini, S. Rescic, F. Fratini, G. Botticelli, Ammonium phosphates as consolidating agents for carbonatic stone materials used in architecture and cultural heritage: Preliminary research, Int. J. Archit. Herit. 5 (2011) 717-736.

[6] E. Sassoni, S. Naidu, G.W. Scherer, The use of hydroxyapatite as a new inorganic consolidant for damaged carbonate stones, J. Cult. Herit. 12 (2011) 346-355. 
[7] S. Naidu, G.W. Scherer, Development of hydroxyapatite films to reduce the dissolution rate of marble, Proceedings of 12th International Congress on Deterioration and Conservation of Stone, New York City (USA), (2012) 1-9.

[8] E. Sassoni, E. Franzoni, B. Pigino, G.W. Scherer, S. Naidu, Consolidation of calcareous and siliceous sandstones by hydroxyapatite: Comparison with a TEOS-based consolidant, J. Cult. Herit. 14 (2013) e103-e108.

[9] S.H. Holickova, The use of Di-ammonium Hydrogen Phosphate in consolidation of calcareous stone, Thesis, Göteborgs University (2015).

[10] C. Blasi, G. Cacudi, A. Di Marzo, M.Matteini, The Church of Santa Croce in Lecce: critical analysis of the restoration of the façade XXXII, Convegno Internazionale Scienza e Beni Culturali, Bressanone (2016) 501-513.

[11] R. Liu, X. Han, X. Huang, W. Li, H. Luo, Preparation of three-component TEOS-based composites for stone conservation by sol-gel process, J. Sol-Gel Sci. Technol. 68 (2013) 19-30.

[12] C. Salazar-Hernández, J. Cervantes, M.J. Puy-Alquiza, R. Miranda, Conservation of building materials of historic monuments using a hybrid formulation, J. Cult. Herit. 16 (2015) 185-91.

[13] E. Franzoni, E. Sassoni, G. Graziani, Brushing, poultice or immersion? The role of the application technique on the performance of a novel hydroxyapatite-based consolidating treatment for limestone, $\mathrm{J}$. Cult. Herit. 16 (2015) 173-184.

[14] E. Sassoni, G. Graziani, E. Franzoni, Repair of sugaring marble by ammonium phosphate: Comparison with ethyl silicate and ammonium oxalate and pilot application to historic artifact, Mater. Des. 88 (2015) 1145-1157.

[15] A. Sierra-Fernandez, L.S. Gomez-Villalba, M.E. Rabanal, R. Fort, New nanomaterials for applications in conservation and restoration of stony materials: A review, Mater. Construcción 67 (2017) 0465-2746.

[16] E. Sassoni, Hydroxyapatite And Other calcium phosphates for the conservation of cultural heritage: A review, Materials 11 (2018) 1-48.

[17] M.L. Weththimuni, M. Licchelli, M. Malagodi, N. Rovella, M. La Russa, Consolidation of biocalcarenite stone by treatment based on diammonium hydrogenphosphate and calcium hydroxide nanoparticles, Meas. J. Int. Meas. Confed. 127 (2018) 396-405.

[18] F. Xu, D. Li, The use of CTAB as an addition of DAP for improvement resisting acid rain on limestone, Appl. Surf. Sci. 422 (2017) 1059-1066.

[19] B.C. Barriuso, G. Botticelli, O.A. Cuzman, I. Osticioli, P. Tiano, M. Matteini, Conservation of calcareous stone monuments: Screening different diammonium phosphate based formulations for countering phototrophic colonization, J. Cult. Herit. 27 (2017) 97-106.

[20] E. Sassoni, S. Andreotti, G.W. Scherer, E. Franzoni, S. Siegesmund, Bowing of marble slabs: can the phenomenon be arrested and prevented by inorganic treatments?, Environ. Earth Sci. 10 (2018) 77-387.

[21] D. T. Nicholson, F. H. Nicholson, Physical deterioration of sedimentary rocks subjected to experimental freeze-thaw weathering, Earth Surface Processes and Landforms: The Journal of the British Geomorphological Research Group 25.12 (2000): 1295-1307.

[22] A.E. Charola, Salts in the deterioration of porous materials: an overview, Journal of the American institute for conservation39.3 (2000): 327-343.

[23] V. Shushakova, E. R. Fuller, S. Siegesmund, Microcracking in calcite and dolomite marble: microstructural influences and effects on properties, Environ. Earth Sci 69.4 (2013): 1263-1279.

[24] E. Sassoni, E. Franzoni, Influence of porosity on artificial deterioration of marble and limestone by heating, Appl. Phys. A. Mater. 115 (2014) 809-816, https://doi.org/10.1007/s00339-013-7863-4

[25] G.F. Andriani, L. Germinario, Thermal decay of carbonate dimension stones: fabric, physical and mechanical changes, Environ. Earth Sci 72.7 (2014): 2523-2539.

[26] L. Lazzarini, M. Laurenzi Tabasso, Il restauro della pietra, CEDAM (1986)1-317.

[27] A.P.F. Pinto, J.D. Rodrigues, Stone consolidation: The role of treatment procedures, J. Cult. Herit. 9 (2008) 38-53.

[28] A.P. Ferreira Pinto, J. Delgado Rodrigues, Consolidation of carbonate stones: Influence of treatment procedures on the strengthening action of consolidants, J. Cult. Herit. 13 (2012) 154- 166.

[29] M. Kamiya, J. Hatta, E. Shimada, Y. Ikuma, M. Yoshimura, H. Monma, AFM analysis of initial stage of reaction between calcite and phosphate, Mater. Sci. Eng. B Solid-State Mater. Adv. Technol. 111 (2004) 226-231. 
[30] D.G. Kanellopoulou, P.G. Koutsoukos, Inorganic coatings for the protection of marble surfaces from deterioration., Chem. Ind. Chem. Eng. Q. 11 (2005) 161-168.

[31] S. Naidu, G.W. Scherer, Nucleation, growth and evolution of calcium phosphate films on calcite, J. Colloid Interface Sci. 435 (2014) 128-137.

[32] S. Naidu, Novel Hydroxyapatite Coatings for the Conservation of Marble and Limestone, Dissertations PhD Theses, Princeton University, (2014); ISBN: 9781321020250.

[33] M. Balonis-Sant, X. Ma, I. Kakoulli, Preliminary results on biomimetic methods based on soluble ammonium phosphate precursors for the consolidation of archaeological wall paintings, in: ACS Symp. Ser., 1147 (2013) 419-447.

[34] S. Naidu, J. Blair, G.W. Scherer, Acid-resistant coatings on marble, J. Am. Ceram. Soc. 99 (2016) 3421-3428.

[35] E. Possenti, C. Colombo, D. Bersani, M. Bertasa, A. Botteon, C. Conti, P.P. Lottici, M. Realini, New insight on the interaction of diammonium hydrogenphosphate conservation treatment with carbonatic substrates: A multi-analytical approach, Microchem. J. 127 (2016) 79-86.

[36] G. Graziani, E. Sassoni, G.W. Scherer, E. Franzoni, Penetration depth and redistribution of an aqueous ammonium phosphate solution used for porous limestone consolidation by brushing and immersion, Constr. Build. Mater. 148 (2017) 571-578.

[37] L. Carmignani, P. Conti, P. Fantozzi, S. Mancini, G. Massa, G. Molli, L. Vaselli, I marmi delle Alpi Apuane.Geo. Italia (2007) 19-31.

[38] P. Blasi, A. Criscuolo, S. Lisi, Il Marmo di Carrara: aspetti geologici, merceologici e minerari, Eurominerals and the Society of Mining Professors, 1998, September 12-16 Carrara, Italy porous rock: San Julian's calcarenite, Eng. Geol. 167 (2013) 117-127.

[39] P. Primavori,Carrara Marble: a nomination for 'Global Heritage Stone Resource'from Italy, Geol. Soc. London Spec. Publ. 407 (2015) 137-154.

[40] C.M. Belfiore, M. Ricca, M.F. La Russa, S.A. Ruffolo, G. Galli, D. Barca, M. Malagodi, M. Vallefuoco, M. Sprovieri, A. Pezzino, Provenance study of building and statuary marbles from the Roman archaeological site of "Villa dei Quintili" (Rome, Italy), Ital. J. Geosci. 135 (2016) 236-249.

[41] M. Vallefuoco, M. Sprovieri, A. Pezzino, Provenance study of building and statuary marbles from the Roman archaeological site of "Villa dei Quintili" (Rome, Italy), Ital. J. Geosci. 135 (2016) 236-249.

[42] A. Murru, D.M. Freire-lista, R. Fort, M.J. Varas-muriel, P. Meloni, Evaluation of post- thermal shock effects in Carrara marble and Santa Caterina di Pittinuri limestone, Constr. Build. Mater. 186 (2018) $1200-1211$.

[43] L. Carmignani, G. Oggiano, S. Barca, P. Conti, I. Salvadori, A. Eltrudis, A. Funedda, S. Pasci, Geologia della Sardegna (Note illustrative della Carta Geologica della Sardegna in scala 1: 200.000), Memorie descrittive della Carta geologica d'Italia, 60 (2001) 1-283.

[44] E. Franzoni, E. Sassoni, G.W. Scherer, S. Naidu, Artificial weathering of stone by heating, J. Cult. Herit. 14 (2013) e85-e93.

[45] M. Gomez-Heras, S. McCabe, B.J. Smith, R. Fort, Impacts of fire on stone-built Heritage: An overview, J. Archit. Conserv. 2 (2009) 47-59.

[46] E. Sassoni, G. Graziani, E. Franzoni, G.W. Scherer, Some Recent Findings on Marble Conservation by Aqueous Solutions of Diammonium Hydrogen Phosphate, in: MRS Adv., 2 (2017) 2021-2026.

[47] X. Ma, M. Balonis, H. Pasco, M. Toumazou, D. Counts, I. Kakoulli, Evaluation of hydroxyapatite effects for the consolidation of a Hellenistic-Roman rock-cut chamber tomb at Athienou-Malloura in Cyprus, Constr. Build. Mater. 150 (2017) 333-344.

[48] E. Sassoni, G. Graziani, E. Franzoni, Repair of sugaring marble by ammonium phosphate: Comparison with ethyl silicate and ammonium oxalate and pilot application to historic artifact, Mater. Des. 88 (2015) 1145-1157.

[49] E. Sassoni, E. D’Amen, N. Roveri, G.W. Scherer, E. Franzoni, Durable self-cleaning coatings for architectural surfaces by incorporation of $\mathrm{TiO} 2$ nano-particles into hydroxyapatite films, Materials 11 (2018) 177.

[50] A.Murru, Consolidamento di supporti lapidei carbonatici caratterizzanti i beni culturali attraverso formulati inorganici mineralizzanti: applicazione ed efficacia, Dissertation $\mathrm{PhD}$ thesis Thesis, Università degli Studi di Cagliari, Italy (2017).

[51] S. A. Russell, Stone preservation committee report (Appendix I), HM Stationary Office, London (1927). 
[52] J. Guyader, A. Denis, Propagation des ondes dans les roches anisotropes sous contrainte évaluation de la qualité des schistes ardoisiers, Bull. Int. Assoc. Eng. Geol. - Bull. l'Association Int. Géologie l’Ingénieur. 33 (1986) 49-55.

[53] R. Fort, M.J. Varas, M. Alvarez De Buergo, D. Martin-Freire, Determination of anisotropy to enhance the durability of natural stone, J. Geophys. Eng. 8 (2011) 132-144.

[54] R. Fort, Aplicación de la Técnica de propagación de ondas ultrasónicas en el patrimonio pétreo, Durabilidad y conservación de materiales tradicionales naturales del patrimonio arquitectónico, Ed. Instituto Tecnológico de Rocas Ornamentales y Materiales de Construcción (INTROMAC). Junta de Extremadura, (2008) 107-133, ISBN: 978-84-691-5918-7.

[55] B. Christaras, F. Auger, E. Mosse, Determination of the moduli of elasticity of rocks. Comparison of the ultrasonic velocity and mechanical resonance frequency methods with direct static methods, Mater. Struct. 27 (1994) 222-228, https://doi.org/10.1007/BF02473036.

[56] CIE S014-4/E:2007. Colorimetry Part 4: CIE 1976 L*a*b* Colour Space. Commission Internationale de l'eclairage, CIE Central Bureau, Vienna (2007).

[57] UNI EN 15886:2010, Conservation of cultural property - Test methods - Colour measurement of surfaces.

[58] W. S. Mokrzycki, M. Tatol, Colour difference $\Delta$ E-A survey, Machine Graphics and Vision 20.4 (2011): 383-411.

[59] .E.S. Gadelmawla, M.M. Koura, T.M.A. Maksoud, I.M. Elewa, H.H. Soliman, Roughness parameters, J. Mater. Process. Technol. 123 (2002) 133-145.

[60] I. Osticioli, G. Botticelli, P. Matteini, S. Siano, R. Pini, M. Matteini, Micro-Raman analysis on the combined use of ammonium oxalate and ammonium phosphate for the consolidation and protection of carbonate stone artifacts, J. Raman Spectrosc. 48 (2017) -971.

[61] E. Sassoni, G. Graziani, E. Franzoni, An innovative phosphate-based consolidant for limestone. Part 2: Durability in comparison with ethyl silicate, Constr. Build. Mater. 102 (2016) 918-930.

[62] P.L. Mameli, Problemi di consolidamento di matrici lapidee di differente microstruttura esposte a sollecitazioni ambientali e microclimatiche di varia origine, Dissertation PhD thesis, Alma Mater Studiorum Università di Bologna (2012).

[63] E. Molina, C. Fiol, G. Cultrone, Assessment of the efficacy of ethyl silicate and dibasic ammonium phosphate consolidants in improving the durability of two building sandstones from Andalusia (Spain), Environ. Earth Sci. 77 (2018) 302.

[64] Benavente, D., Martínez-Verdú, F, Bernabéu A, Viqueira, V. Fort, R, García Del Cura, M.A Illueca, C., Ordóñez, S..Influence of Surface Roughness on Color Changes in Building Stones Color Research and Application. 28, n5, 343-351. 
Figure 1. Geometry and sample size

Geometry and size of thermally aged samples used in: a) consolidant absorption, UPV, colour and roughness analysis; b) MIP analysis; c) SEM-EDX analysis

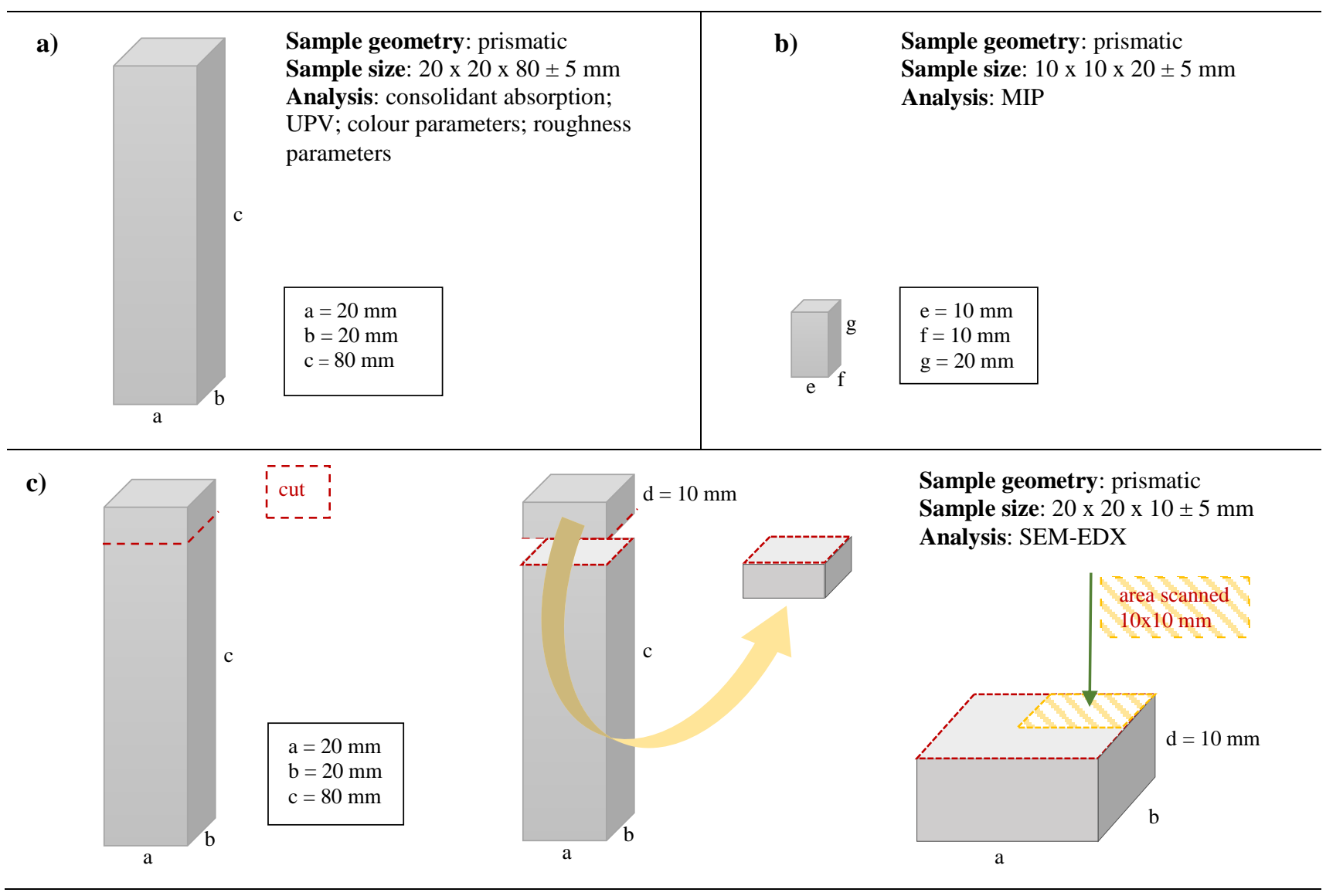




\section{Figure 2. Water sorptivity}

Capillary water absorption in artificially aged marble and limestone samples (dotted line: $2 \mathrm{~h}$ of capillary absorption)

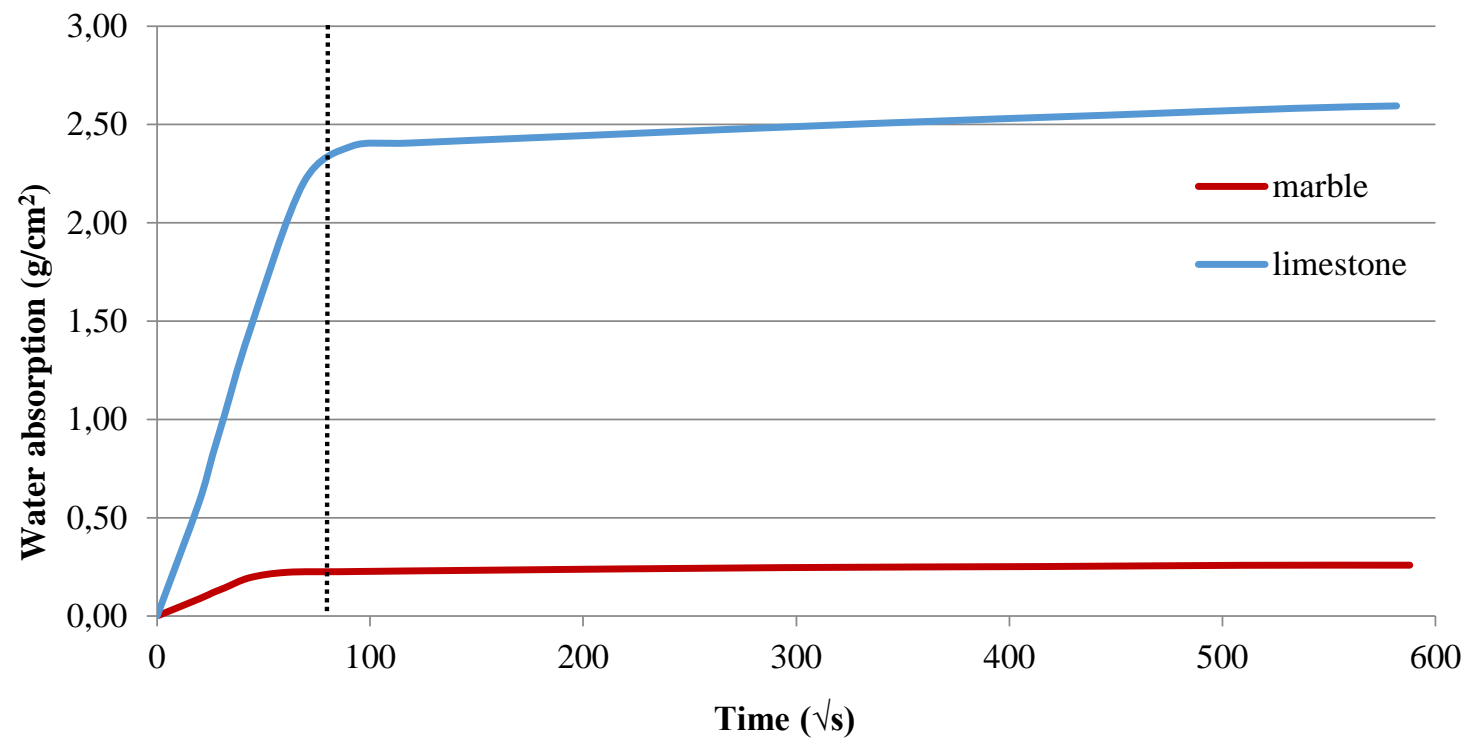


Figure 3. SEM-EDX analysis

SEM-EDX imaging with phosphate intensity diagram and phosphorous distribution (PK $\alpha$ ) map; a) and d) stone consolidated by brushing; b) and e) stone consolidated by immersion; c) and f) stone consolidated by poultice packing

MARBLE

Electron image

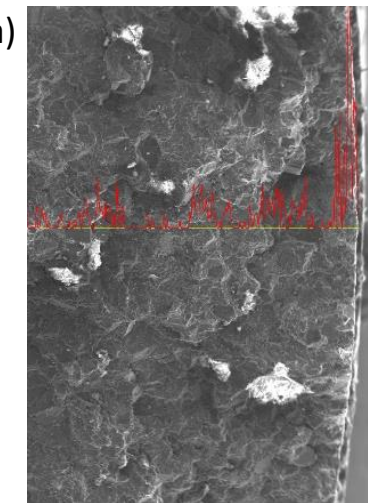

b)

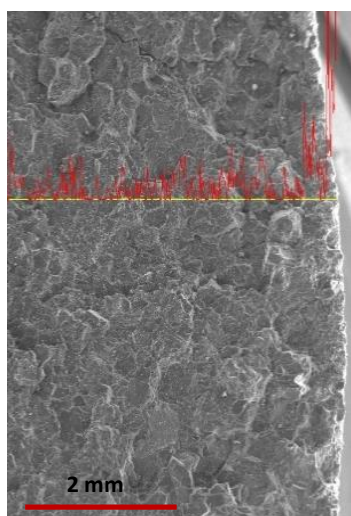

c)

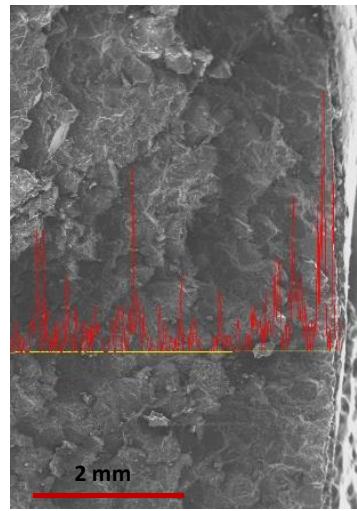

Phosphorous Ka1
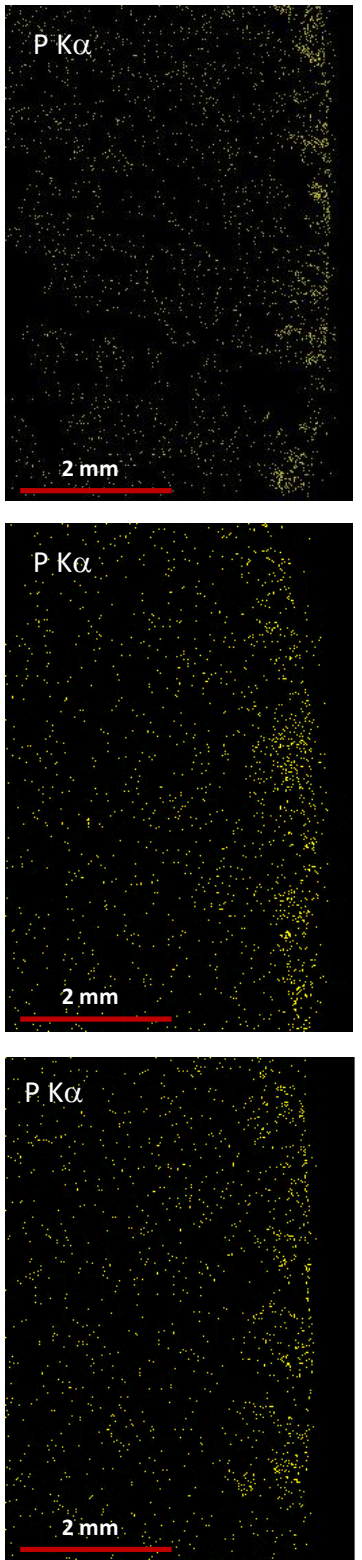

LIMESTONE

Electron image

Phosphorous Ka1

d)
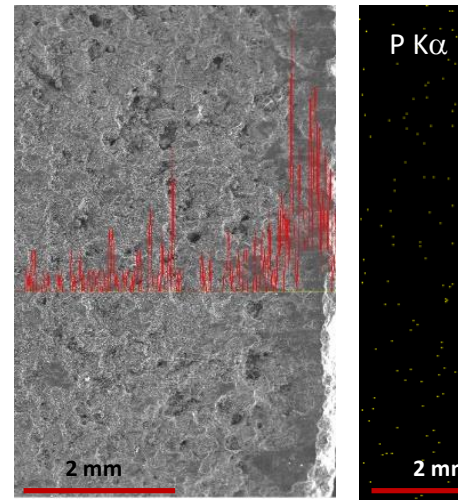

e)

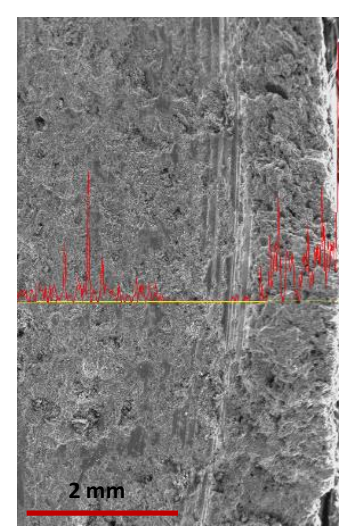

$2 \mathrm{~mm}$

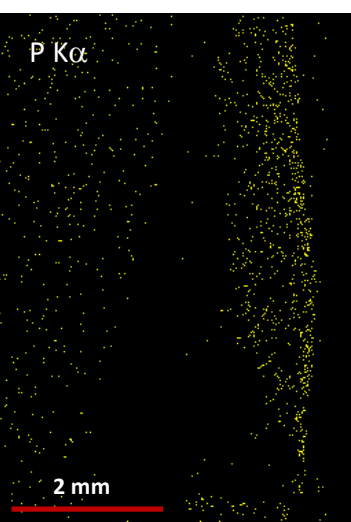

f)

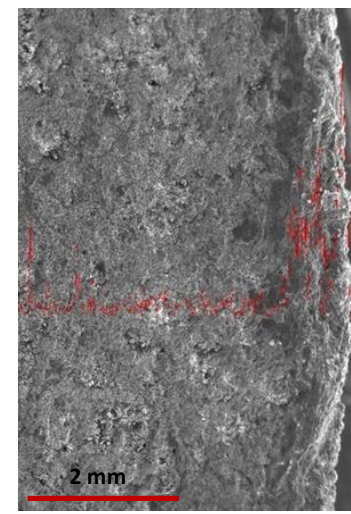

P. Ka

P Ka

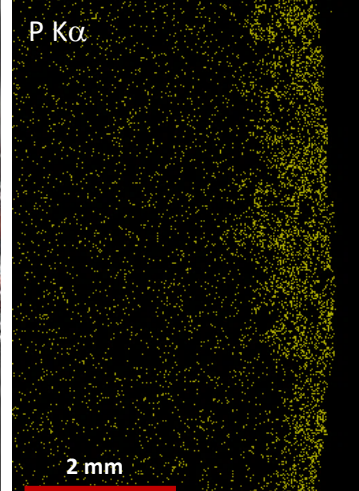


Figure 4. Mercury intrusion porosimetry analysis

Pore size distribution in marble and limestone
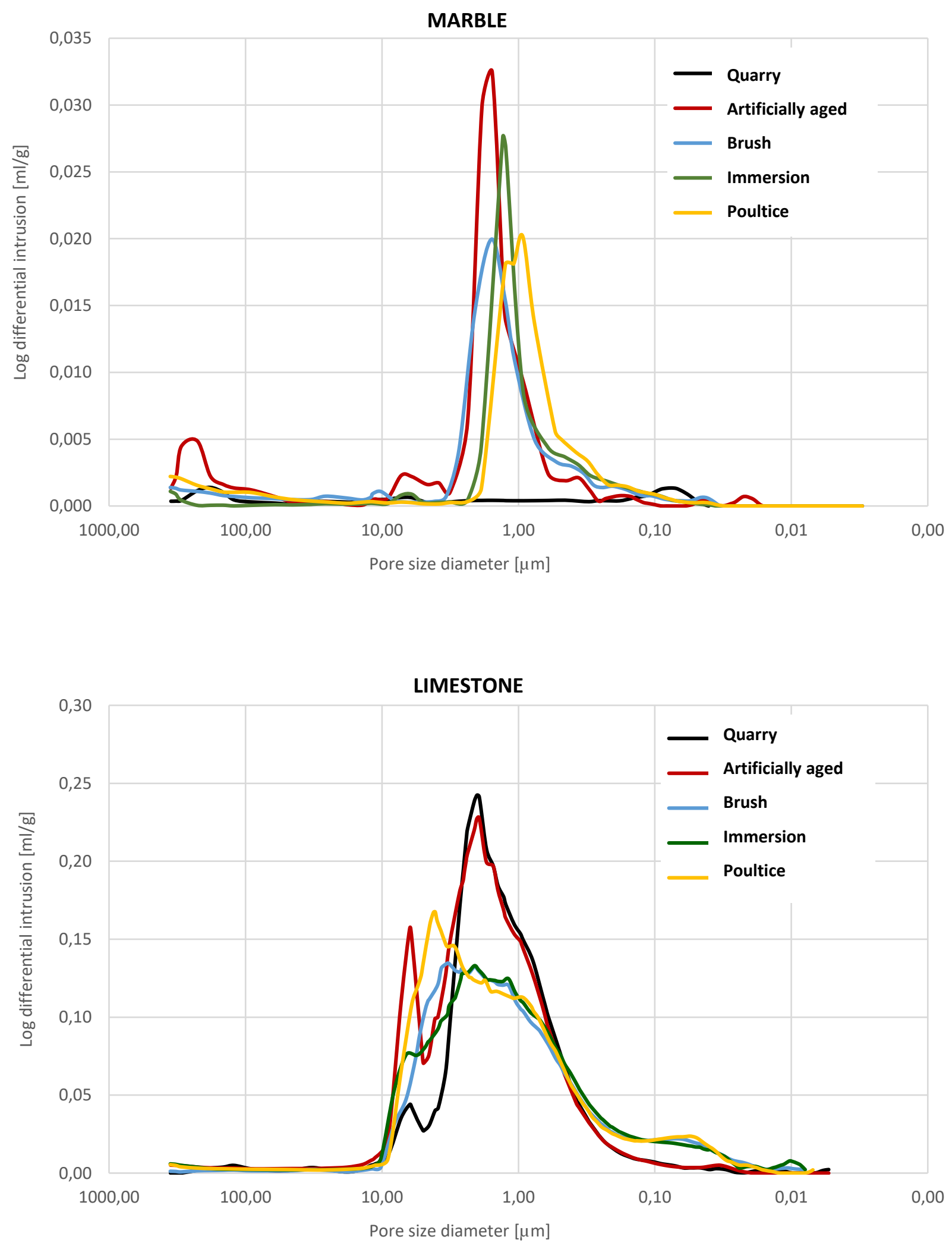


\section{Figure 5. Roughness parameters}

Marble and limestone roughness in: a) and f) unaltered quarry stone; b) and g), artificially aged stone; c) and h) stone consolidated by brushing; d) and i) stone consolidated by immersion; e and j) stone consolidated by poultice packing
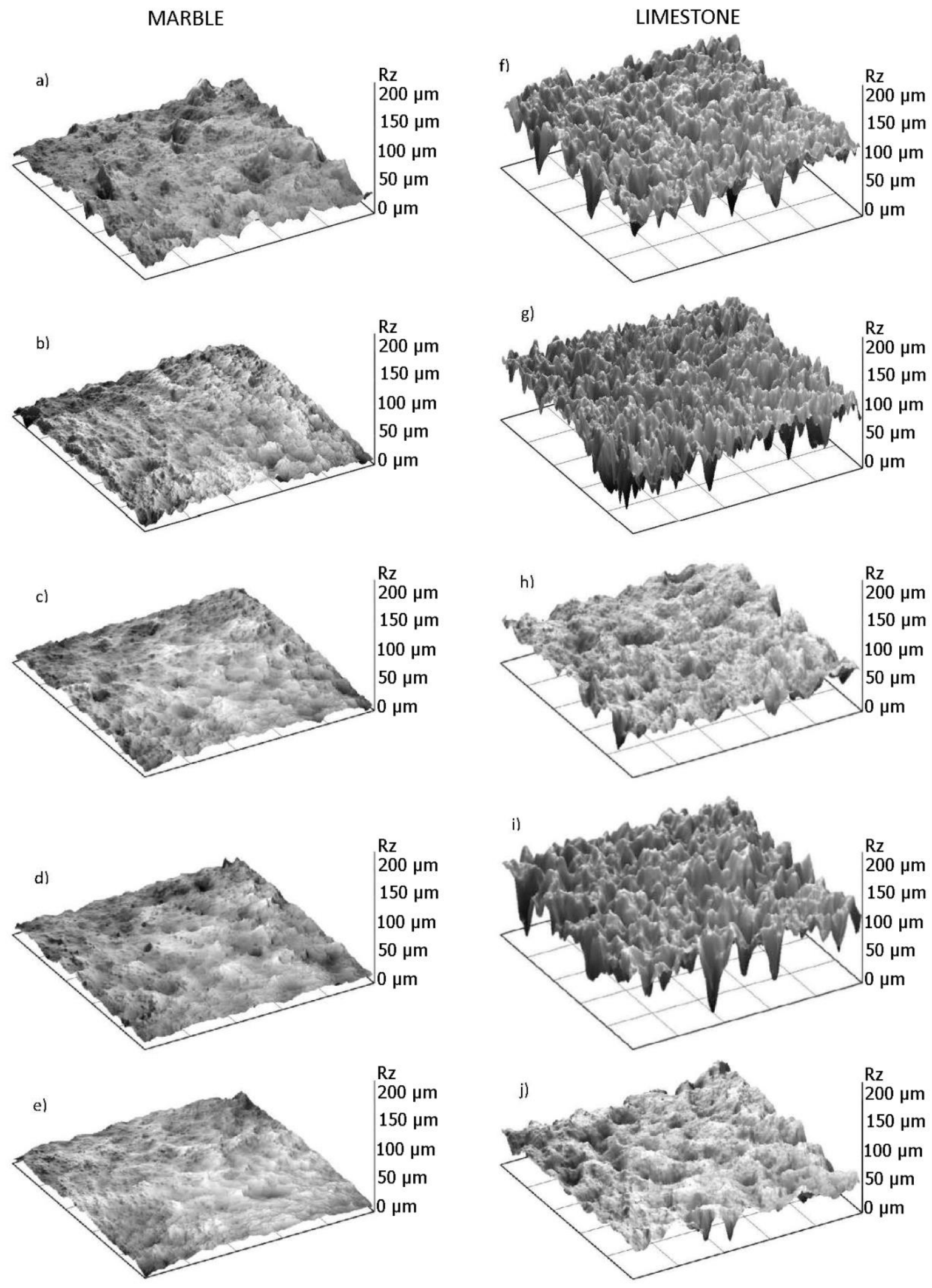
Figure 6. Summary of results

Application technique effectiveness: red, least effective or liable to cause secondary damage; orange, intermediate effects; green, best performance

\begin{tabular}{c|c|c|c|c|c|c}
\multirow{2}{*}{} & \multicolumn{3}{c|}{ MARBLE } & \multicolumn{3}{c}{ LIMESTONE } \\
\cline { 4 - 7 } & Brush & Immersion & Poultice & Brush & Immersion & Poultice \\
\hline Active product & & & & & & \\
\hline Penetration & & & & & & \\
\hline Porosity & & & & & & \\
\hline Microporosity & & & & & & \\
\hline UPV & & & & & & \\
\hline Anisotropy & & & & & & \\
\hline Alteration index & & & & & & \\
\hline $\begin{array}{c}\text { Young's dynamic } \\
\text { modules }\end{array}$ & & & & & & \\
\hline Roughness & & & & & & \\
\hline Colour & & & & & & \\
\hline
\end{tabular}

